\title{
Health on the hill: Six health bills to watch
}

\author{
Cite as: CMAJ 2017 November 6;189:E1373-4. doi: 10.1503/cmaj.109-5514
}

Posted on cmajnews.com on Oct. 18, 2017.

$\mathrm{T}$

here are six active health bills in the pipeline as parliament returns from its Thanksgiving break.

\section{Bill C-277, the framework on palliative care in Canada act}

This Conservative private member's bill would see the government develop a national framework to define palliative care services, identify training requirements, and include plans for improving access and data collection. The bill also directs the government to consider reestablishing a palliative care secretariat at Health Canada.

Fewer than $30 \%$ of Canadians have access to palliative care, said bill sponsor MP Marilyn Gladu. Offering assisted death without ensuring access to good quality palliative care "would be no true choice."

The bill passed the House of Commons with strong support across the aisle, but only after the removal of a requirement to consider covering palliative care under the Canada Health Act. "Given the complexity of the Canada Health Act, there is a real risk that this measure would lead to lengthy delays in the implementation of the framework, when more immediate action is needed," said Joel Lightbound, parliamentary secretary to the minister of health.

It's now before the Senate Committee on Social Affairs, Science and Technology.

Bill C-211, the federal framework on post-traumatic stress disorder act

Another Conservative private member's bill that has received strong all-party support, Bill C-211, calls on the government to develop a comprehensive plan to address the challenges of timely recognition, diagnosis and treatment of post-traumatic stress disorder (PTSD). To do this, the bill requires the minister of health to convene a conference with the ministers of national defence,

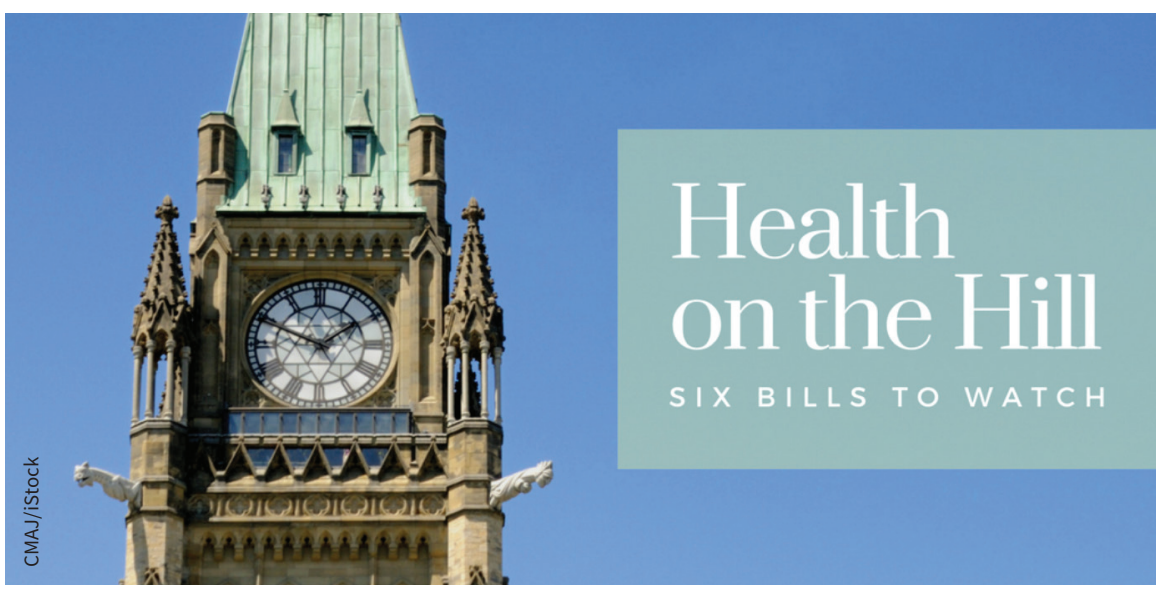

A palliative care framework, new vaping rules and legal pot are up for debate in the House and Senate.

veterans affairs and public safety, as well as representatives of the provinces and territories, medical community and patient groups.

The bill was prompted by the suicides of first responders and a veteran with PTSD. "It is my sincere hope that with this private member's bill, the men and women who are our silent sentinels know that they are not alone in this," said bill sponsor MP Todd Doherty.

The bill has passed the House and is now at second reading in the Senate.

\section{Bill S-5, vaping regulations and} tobacco plain packaging rules

This Senate bill would create federal regulations for vaping products similar to those for tobacco, including bans on sales to minors and flavours that appeal to youth. The bill would restrict advertising of vaping products, increase penalties for tobacco-related offences, and introduce plain-packaging requirements for tobacco products. However, it allows some flexibility for health workers to promote vaping as an alternative to smoking.

"This bill strikes a balance between the harms from vaping products if they entice youth to develop a nicotine addiction and the public health benefit if they contribute to reducing tobacco-related death and disease," said Senator Chantal Petitclerc.

While vaping companies welcomed the government's flexible approach, the tobacco industry argues that plain packaging will make it harder to recognize and restrict contraband products. The bill passed the Senate and is now at second reading in the House, where debate is being watched closely as a precedent for cannabis packaging rules.

\section{Bill C-45, the cannabis act}

The Liberal government's cannabis bill returns to the House for third reading, after a parliamentary committee axed height limits on home-grown marijuana plants and added a requirement that edibles be legalized within a year of the bill becoming law.

New Democrat members and some public health experts argued it didn't make sense to legalize forms of the drug that are smoked, when ingesting is possibly less harmful. Conservative members opposed the legalization of edibles and growing pot at home, arguing both put children at greater risk of ingesting the drug by mistake. 
The Liberals' decision to set the legal age for purchasing cannabis at 18 also remains contentious. The Canadian Medical Association, Canadian Paediatric Society, Canadian Psychiatric Society and Centre for Addiction and Mental Health have warned that the drug can harm the brain, which continues maturing to age 25. "Simply put, cannabis should not be used by young people," CMAJ interim editor-in-chief Dr. Diane Kelsall explained in a recent editorial. She also highlighted "grave concern that legalization of marijuana will result in a substantial increase in impaired driving."

Debate of the bill will resume soon, possibly as early as the week of Oct. 23 .

\section{Bill S-228, the child health protection act}

Senator Nancy Greene Raine championed this bill to prohibit the marketing of unhealthy foods and beverages to children under age 17. Canada is facing a child obesity crisis and advertising plays a role in encouraging unhealthy diets, she said. "For every hour of TV they watch, their consumption of calories goes up, and not just because they are eating snacks; it's because they are seeing the messaging."

The bill was passed unanimously by the Senate without amendment and is now before the House.

\section{Bill C-326, an act to amend drinking water guidelines}

This Liberal private-member's bill would require the government to report annually on how Canada's drinking water standards compare to those of peer nations in the Organisation for Economic Cooperation and Development.

Currently, only eight of Canada's 13 provinces and territories have legally enforceable drinking water standards, said bill sponsor MP Francis Scarpaleggia. "The bill would require that the government, after comparing specific Canadian standards with another country's higher standard for a particular contaminant, publicly justify why Canada is not adopting that other country's superior standard, or conversely why we need to."

The bill won support from members of the three major parties, several of whom highlighted longstanding problems with water quality in Indigenous communities. However, Kevin Lamoureux, parliamentary secretary to the leader of the government, noted that the bill may need to be tweaked to recognize that "provincial jurisdictions also have a very important role, and even our municipalities."

The bill is currently at second reading in the House and may next head to committee.

Lauren Vogel, CMAJ 